\title{
KEBIJAKAN PENDIDIKAN SEBAGAI SUATU KEBIJAKAN PUBLIK: SUATU ANALISIS TERHADAP KEKHUSUSAN KEBIJAKAN PENDIDIKAN DI ACEH
}

\author{
Amirul Haq RD*, Subiyantoro**, Rahmad Syah Putra*** \\ *Universitas Islam Negeri Sunan Kalijaga Yogyakarta \\ **Universitas Islam Negeri Sunan Kalijaga Yogyakarta \\ ***Universitas Islam Negeri Ar-Raniry Banda Aceh, Aceh \\ Email: amirulhaq5839@gmail.com, subiyantoro@uin-suka.ac.id, \\ rahmad.sp@ar-raniry.ac.id
}

\begin{abstract}
Abstrak: Pendidikan merupakan salah satu usaha sadar untuk menciptakan Sumber Daya Manusia yang berkualitas, guna melahirkan Sumber Daya Manusia yang berintelektual dan bermoral maka dibutukan pula suatu kebijakan pendidikan yang mengatur sistem pendidikan, sebagai parameter dalam pelaksanaan pendidikan. Penelitian ini merupakan penelitian kualitatif dengan pendekatan deskriptif menyangkut tentang studi kebijakan publik terhadap kekhususan kebijakan pendidikan Aceh. Studi kebijakan publik dalam penelitian ini dimaksud untuk mengeksplorasi berbagai tindakan yang dilakukan pemerintah, untuk kepentingan siapa, dan bagaimana hasil, akibat dan dampaknya. Adapun subjek penelitian ini diambil dengan cara purposive sampling, dengan metode pengumpulan data dilakukan melalui 3 (tiga) macam cara yaitu; 1) observasi; 2) wawancara; dan 3) dokumentasi yaitu menganalisis isi kebijakan (content analysis), mengkaji dokumen-dokumen berupa kategori administratif maupun substantif, diantaranya berupa berbagai bentuk kertas kerja hingga naskah akademik suatu kebijakan pendidikan di Aceh. Setelah rangkaian data terkumpul, selanjutnya dilakukan pula analisis data dengan 4 (empat) tahap dan prosedur pengolahan data yaitu: 1) pemilahan/penyusunan klasifikasi data, 2) penyuntingan data, 3) konfirmasi/verifikasi/pendalaman data, dan 4) analisis data sesuai dengan konstruksi pembahasan hasil penelitian. Berdasarkan hasil penelitian menunjukkan bahwa Pemerintah Aceh telah merumuskan suatu kebijakan publik tentang pendidikan di Aceh yaitu Qanun Aceh Nomor 11 Tahun 2014 tentang Penyelenggaraan Pendidikan, dan Qanun Aceh Nomor 9 Tahun 2015 tentang Perubahan Atas Qanun Aceh Nomor 11 Tahun 2014 tentang Penyelenggaraan Pendidikan, alasan utama dilakukan perumusan kebijakan khusus pendidikan Aceh diantaranya ialah sebagai bentuk implementasi dari Undang-Undang Nomor 11 Tahun 2006 tentang Pemerintah Aceh. Melalui kebijakan yang telah dirumuskan berdasarkan Qanun Aceh itu pula, Pemerintah Aceh sangat menghendaki agar sistem pendidikan dikembangkan dengan menekankan pola Sistem Pendidikan Islami atau Sistem Pendidikan Berbasis Nilai-Nilai
\end{abstract} Islami (penekanannya pada penanaman nilai-nilai Islami dan pengembangan budaya islami).

Kata Kunci: Kebijakan Pendidikan, Kebijakan Publik, dan Pendidikan Aceh

\begin{abstract}
Education is one of the conscious efforts to create quality human resources, in order to produce intellectual and moral human resources an education policy that regulates the education system is also needed, as a parameter in the implementation of education. This research is a qualitative research with a descriptive approach concerning the study of public policy on the specificities of Aceh's education policy. Public policy studies in this research are
\end{abstract}


intended to explore various actions taken by the government, for whose interests, and how the results, consequences and impacts. The subject of this study was taken by purposive sampling, with data collection methods carried out in 3 (three) kinds of ways, namely; 1) observation; 2) interview; and 3) documentation, namely analyzing the content of policies (content analysis), reviewing documents in the form of administrative and substantive categories, including various forms of working papers to academic texts of an education policy in Aceh. After the data series is collected, data analysis is also carried out with 4 (four) stages and data processing procedures, namely: 1) sorting / compiling data classification, 2) editing data, 3) data confirmation / verification / deepening, and 4) data analysis according to with the construction of the discussion of research results. Based on the results of the research, it shows that the Aceh Government has formulated a public policy on education in Aceh, namely Aceh Qanun Number 11 of 2014 concerning the Implementation of Education, and Aceh Qanun Number 9 of 2015 concerning Amendments to Aceh Qanun Number 11 of 2014 concerning the Implementation of Education, the main reason for this was The formulation of special policies for Aceh's education includes the implementation of Law Number 11 of 2006 concerning the Government of Aceh. Through the policies that have been formulated based on the Aceh Qanun, the Aceh Government strongly wants the education system to be developed by emphasizing the Islamic Education System or Islamic Values-Based Education System (the emphasis is on planting Islamic values and developing Islamic culture).

Keywords: Education Policy, Public Policy, and Aceh Education

\section{PENDAHULUAN}

Berbicara mengenai suatu kebijakan, tidak terlepas dari suatu bentuk regulasi yang mengikat dan lahir sebagai produk politik dengan tujuan untuk merealisasikan suatu tujuan. Sebagai suatu bentuk kebijakan, ditinjau dari konteks sejarah lahirnya produk kebijakan, suatu kebijakan tersebut lahir tidak terlepas pula dari persoalanpersoalan yang timbul banyak dalam suatu masyarakat. Sehingga menuntut untuk dilakukan pemecahan persoalan tersebut agar melahirkan solusi kongkrit untuk bangsa.

Seiring dengan perkembangan Negara Indonesia, telah banyak pula lahir berbagai produk kebijakan, dengan proses pembuatan tersebut tidak terlepas pula dari proses politik. Hingga saat ini, proses perumusan kebijakan terus dilakukan, seiring dengan perkembangan dan dimanika yang berkembang dalam masyarakat. Kebijakankebijakan tersebut, tentunya dirumuskan dalam bentuk regulasi yang ada dengan harapan untuk dapat mewujudkan kesejahteraan bangsa Indonesia sebagaimana yang diamanatkan dalam Undang-Undang Dasar Negara Republik Indonesia (UUD) 1945 dan Sila ke-4 dan Ke-5 dari Pancasila sebagai ideologi bangsa yaitu: kerakyatan yang dipimpin oleh hikmat kebijaksanaan dalam permusyawaratan dan perwakilan, dan keadilan sosial bagi seluruh rakyat Indonesia. ${ }^{1}$

\footnotetext{
${ }^{1}$ Majelis Permusyawaratan Rakyat Republik Indonesia, Materi Sosialisasi Empat Pilar MPR RI, (Jakarta; Sekretariat Jenderal MPR RI, 2017), h. 1-5.
} 
Jika kita melihat dari sila ke-4 dan 5 di atas pula, tentu sangat jelas bahwa tujuan suatu kebijakan yang dilahirkan oleh Pemerintah tidak lain ialah untuk mewujudkan keadilan bagi seluruh rakyat, yang diwujudkan dalam bentuk implementasi kebijakan disegala bidang, mulai dari bidang ekonomi, politik, budaya, agama, suku/rasa, hingga pendidikan. Kebijakan tersebut tentunya dilahirkan dalam berbagai bentuk pula, mulai dari Undang-Undang, Peraturan Presiden, Keputusan Presiden, Peraturan Pemerintah, Peraturan Menteri, Keputusan Menteri, Peraturan Daerah Provinsi, Keputusan Gubernur, Surat Edaran, Keputusan Kepala Dinas, Peraturan Daerah Kabupaten/Kota, Keputusan Bupati/Walikota, Keputusan Kepala Dinas Kabupaten/Kota, Surat Edaran Bupati/Walikota dan lain sebagainya. Dari sini pula terlihat jelas bahwa, semua kebijakan tersebut bertujuan untuk Rakyat dalam rangka untuk menjamin kepentingan umum semaksimal mungkin.

Dalam bidang pendidikan, lahirnya suatu kebijakan tidak terlepas pula dari persoalan penting suatu bangsa, dimana kebijakan pendidikan tersebut lahir akibat dari terjadinya suatu pergeseran yang terjadi, seiring dengan dinamika yang berkembang, baik di tingkat regional, nasional, maupun internasional. Pendidikan merupakan sektor penting dalam proses pembangunan nasional dalam rangka meningkatkan kualitas sumber daya manusia suatu negara. ${ }^{2}$ Tentunya, adanya suatu kebijakan dalam bidang pendidikan tidak lain ialah dalam rangka untuk meningkatkan daya saing suatu bangsa agar maju dan sejajar dengan bangsa-bangsa lain di luar. Hal ini tentunya sejalan sebagaimana telah dituangkan dalam Pembukaan Undang-Undang Dasar (UUD) 1945 alinea ke-4 diantaranya ialah untuk memajukan kesejahteraan umum, dan mencerdaskan kehidupan bangsa, ${ }^{3}$ dengan implikasinya ialah peningkatan kapasitas warga Negara Indonesia dalam bidang pendidikan, sehingga makmur dan memiliki pengetahuan.

Pengkajian terhadap kebijakan dalam bidang pendidikan sebagai kebijakan publik diperlukan mengingat sektor pendidikan adalah suatu sektor penting untuk menghasilkan produk jasa pendidikan yang baik sebagai ujung tombak agar menjadi maju dan berdaya saing. Pendidikan menjadi salah satu faktor utama dalam rangka pembangunan Sumber Daya Manusia. Urgensi pembangunan sumber daya manusia menjadi faktor kunci keberhasilan sebuah daerah, terutama dalam rangka untuk pengelolaan dan pemanfaatan Sumber Daya untuk kemajuan daerah. Dalam konteks pembangunan Sumber Daya Manusia, pemerintah daerah maupun provinsi harus memiliki langkah strategis dalam mewujudkan tujuan tersebut, terutama melalui pembangunan dalam bidang pendidikan. Karena, pembangunan sektor pendidikan salah satu investasi dalam jangka panjang, sebab berhubungan dengan investasi modal manusia (human capital). Pentingnya investasi pada sektor pendidikan dalam rangka

${ }^{2}$ Rahmad Syah Putra, Strategi Peningkatan Mutu Pendidikan pada SMA Negeri 3 Meulaboh, dalam Jurnal Administrasi Pendidikan Vol. 5 Nomor 3 Agustus 2017, 163-164.

${ }^{3}$ Majelis Permusyawaratan Rakyat Repulik Indonesia, Undang-Undang Dasar Negara Republik Indonesia Tahun 1945, (Jakarta: Sekretariat Jenderal MPR RI, 2017), h. 1-2. 
untuk mempersiapkan Sumber Daya Manusia di masa depan agar mampu berkontribusi dalam rangka pembangunan suatu daerah berdaya saing, dan berkemajuan melalui pengalaman, dan spesifikasi keilmuan yang dimiliki oleh seseorang. Sehingga, dapat mewujudkan suatu daerah menjadi mandiri, serta masyarakatnya sejahtera dengan tanpa bergantung kepada pemerintah. ${ }^{4}$

Di Aceh sendiri, dalam kontek kebijakan publik telah dirumuskan pula suatu bentuk kebijakan pendidikan, perwujudan kebijakan tersebut direalisasikan pula dengan suatu regulasi atau Peraturan Daerah yang disebut dengan 'Qanun Aceh' yang di dalamnya mengatur secara khusus penyelenggaraan pendidikan di Aceh yaitu Qanun Aceh Nomor 11 Tahun 2014 tentang Penyelenggaraan Pendidikan di Aceh. ${ }^{5}$ Kemudian, dipertegas lagi dengan Qanun Nomor 9 Tahun 2015 (Perubahan atas Qanun Nomor 11 Tahun 2014) tentang Penyelenggaraan Pendidikan di Aceh. ${ }^{6}$ Tujuan dari adanya suatu kebijakan khusus terhadap penyelenggaraan pendidikan di Aceh menjadi isu strategis Pemerintah Aceh guna mensikapi berbagai problematika yang terjadi dalam konteks pendidikan di Aceh, juga sebagai suatu harapan agar pendidikan di Aceh memiliki ciri khas tersendiri yaitu adanya integrasi agama Islam dengan ilmu umum pada lembaga pendidikan di Aceh yang dilaksanakan dalam bentuk diantaranya: 1) Mata Pelajaran; 2) Suasana keagamaannya pada lembaga pendidikannya yang akademis; dan 3) Pengintegrasian Pendidikan Islam ke dalam mata pelajaran umum. ${ }^{7}$ Namun seiring perkembangannya, hingga saat ini kebijakan pendidikan di Aceh belum memiliki dampak yang signifikan dalam implementasi bentuk penyelenggaraan pendidikan seutuhnya di Aceh. Sehingga arah dan pengembangan pendidikan di Aceh terkesan tidak konsisten dan hanya simbul semata. Berdasarkan latar belakang masalah dan isu di atas pula, disini peneliti tertarik untuk menganalisis tentang kebijakan pendidikan di Aceh dan kendala-kendala apasaja selama ini, sehingga dalam implementasi kebijakan pendidikan belum optimal dilaksanakan.

\footnotetext{
${ }^{4}$ Nazamuddin, Pendanaan Pendidikan Aceh Melalui Dana Otonomi Khusus, dalam Pendidikan Aceh: Dinamika dan Harapan, (Yogyakarta: Penerbit Pale Media Prima dan Majelis Pendidikan Aceh (MPA), 2020), h. 1; lihat juga, Rahmad Syah Putra, Reza Hendra Putra, Amirul Haq RD, Konsepsi Ideal Darussalam dalam Perspektif A. Hasjmy sebagai Pusat Pendidikan Islam, dalam Adabiya, Volume 22 No. 2 Agustus (2020), h. 81-82; lihat juga Ruqaiyah \& Rahmad Syah Putra, Pendidikan sebagai Investasi Sumber Daya Manusia untuk Mengelola Sumber Daya Alam, dalam Aceh 2021: Sumber Daya Alam dan Politik, (Banda Aceh: Bandar Publishing, 2021). h. 1.

${ }^{5}$ Pemerintah Aceh, Qanun Aceh Tahun 2014 tentang Penyelenggaraan Pendidikan di Aceh, (Banda Aceh: Biro Hukum Setda Aceh, 2014), h. 1-50.

${ }^{6}$ Pemerintah Aceh, Qanun Aceh Nomor 9 Tahun 2015 tentang Perubahan atas Qanun Nomor 11 Tahun 2014 tentang Penyelenggaraan Pendidikan di Aceh, (Banda Aceh: Biro Hukum Setda Aceh, 2015), h.1-30.

${ }^{7}$ Darwis A. Soelaiman, Kurikulum Aceh, (Banda Aceh: Majelis Pendidikan Aceh, 2018), h.1-3.
} 


\section{LANDASAN TEORI}

\section{Kebijakan dan Kebijakan Publik}

Untuk dapat memahami lebih dalam tentang pendekatan dan proses lahirnya kebijakan publik, maka perlu memberikan pengertian terlebih dahulu tentang kebijakan dan kebijakan publik baik dari segi bahasa, istilah yang dirumuskan oleh para ahli dan sejarah munculnya kata kebijakan itu sendiri. Berikut ini pengertian kebijakan publik secara bahasa dan istilah. Dari segi bahasa, kata 'Kebijakan' diambil dari bahasa Inggris yang bermakna policy, yang kemudian di dalam KBBI diartikan sebagai serangkaian konsep yang dijadikan sebagai garis besar dalam pelaksanaan suatu tindakan, baik menyangkut dengan kepemimpinan, organisasi, individu, maupun pemerintah, dan non-pemerintah/swasta, serta guna mencapai sasaran yang tepat sesuai dengan yang direncanakan. ${ }^{8}$

Menurut Leo Agustino sebagaimana dikutip oleh Taufiqurokhman dalam karyanya yang berjudul Kebijakan Publik mendefinisikan 'kebijakan' sebagai suatu usulan seseorang, kelompok, atau pemerintah berbentuk serangkaian tindakan kegiatan dalam suatu lingkungan, lembaga atau negara untuk mencapai tujuan tertentu dari kebijakan itu sendiri yang mana di dalamnya terdapat bebagai hambatan (kesulitan) dan kesempatan selama proses pelaksanaannya. ${ }^{9}$ Sementara Abdul Wahab menyebutkan bahwa terdapat beberapa pedoman untuk dapat memahami istilah 'kebijakan' itu sendiri, dan dirinya pun telah mencantumkannya 14 point utama untuk memahami 'kebijakan' tersebut dalam karyanya yang berjudul 'Analisis Kebijaksanaan' diantaranya ialah: 1) Kebijakan harus dapat dibedakan dari suatu keputusan; 2) Kebijakan tidak dapat dibedakan serta merta dari administrasi; 3) Suatu kebijakan mencakup hal yang berkaitan dengan perilaku dan harapan: 4) Adanya dan tiadanya suatu tindakan merupakan cangkupan dari kebijakan: 5) Ciri dari kebijakan adalah adanya hasil akhir yang ingin diperoleh/dicapai; 6) Tujuan dan sasaran kebijakan bisa dalam bentuk tertulis maupun tidak; 7) Suatu proses yang dilakukan sepanjang waktu merupakan salah satu sebab lahirnya kebijakan; 8) Kebijakan mencakup relasi sesama antar organisasi maupun diluar organisasi; 9) Kebijakan publik haruslah bersifat iklusif/umum; dan 10) Pendefinisian/perumusan suatu kebijakan dilakukan secara subyektif. ${ }^{10}$

Dari pemaparan di atas, maka penulis dapat menyimpulkan bahwa 'kebijakan' merupakan suatu acuan yang digunakan dalam sebuah kegiatan, dimana kebijakan tersebut berguna sebagai suatu konsep dasar pelaksanaan suatu kegiatan guna mencapai tujuan yang diharapkan, selain itu adanya kebijakan diharapkan juga dapat mengatasi berbagai problem baik individu, maupun orgnaisasi sehingga dapat

\footnotetext{
${ }^{8}$ Kementerian Pendidikan dan Kebudayaan, Kamus Besar Bahasa Indonesia, (Jakarta: Direktorat Pendidikan Kemnterian Pendidikan dan Kebudayaan Republik Indonesia, 2018), h. 80.

${ }^{9}$ Taufiqurokhman, Kebijakan Publik, (Jakarta: Fakultas Ilmu Sosial dan Ilmu Politik Universitas Moestopo Beragama Pers, (2014). h. 2.

${ }^{10}$ Solichin Abdul Wahab, Analisis Kebijaksanaan: Dari Formulasi Ke Implementasi Kebijaksanaan Negara (Jakarta: Bumi Aksara, 2008). h. 40-50
} 
melahirkan solusi dalam menyelesaikan berbagai hambatan, kesulitan, maupun masalah.

Sementara 'kebijakan publik' dalam definisinya dimaknai pula sebagai suatu bagian dari ilmu politik, yang di dalamnya terdapat suatu hubungan antar unit dalam struktur pemerintahan, atau dalam makna lain diistilahkan dengan suatu hubungan suatu elemen dengan negara. Winarmo sebagaimana dikutip dalam Maskuri juga membuat suatu pendefinisian terhadap kebijakan publik sebagai suatu acuan pada apa sebenarnya yang perlu dilakukan, bukan kepada apa yang sebenarnya harus diusulkan dalam mengatasi suatu problem tertentu. ${ }^{11}$ Untuk itu, kata 'kebijakan' ditujukan pada suatu tindakan yang dilakukan oleh satu aktor, baik secara individu maupun lembaga dengan maksud dan tujuan tertentu dalam mengatasi persoalan. Selanjutnya, Nurgoho mengunkapkan 'kebijakan publik' sebagai suatu peraturan perundang-undangan yang dibuat oleh lembaga eksekutif maupun legislatif atau pun sebaliknya. ${ }^{12}$ Lebih lanjut, Sutapa mengungkapkan bahwa dari sekian banyak definisi dari kebijakan publik terdapat dua pendapat yang bisa menjadi rujukan dan kesimpulan yaitu: Pertama, pendapat yang mengatakan bahwa tindakan yang dilakukan pemerintah dikategorikan pada 'Kebijakan Publik.' Kedua, pendapat yang lebih memusatkan fokus kebijakan publik pada pelaksanaannya (policy impelementation). Pendapat pertama melihat kebijakan publik sebagai suatu keputusan pemerintah yang memiliki sasaran tertentu, dan pendapat kedua lebih condong kepada sebab-akibat atau dampak dari kebijakan publik sebagai antisipasi dari apa yang diramalkan sebelumnya. ${ }^{13}$

Pendekatan kebijakan publik memiliki peranan penting terhadap perumusanan kebijakan itu sendiri bahkan berada pada tahap kebijakan itu diterima/ditolak oleh masyarakat. hal ini dapat dilihat dari salah satu kebijakan publik yang beberapa waktu lalu sempat menghebohkan seluruh lapisan masyarakat. Kebijakan tersebut adalah pelegalan terhadap investasi Miras atau minuman beralkohol yang tertuang dalam perpres Nomor 10 Tahun 2021 tentang Bidang Usaha Penanaman Modal yang ditandatangani oleh Presiden Joko Widodo sebagai Kepala Negara pada 2 Februari $2021 .{ }^{14}$ Sehingga memunculkan pro dan kontra dan menjadi pembincangan hangat di seluruh siaran televisi nasional, yang pada akhirnya kebijakan tersebut terpaksa dicabut kembali setelah Presiden mendengar berbagai masukan dari beberapa kelompok masyarakat, seperti ulama dan organisasi masyarakat (ormas) lainnya.

Berkaca pada kasus di atas pula, maka dapat disimpulkan bahwa suatu kebijakan publik memiliki pengaruh yang cukup besar bagi masyarakat, dan setiap

\footnotetext{
${ }^{11}$ Maskuri, "Kebijakan Pendidikan Sebagai Kebijakan Publik Dalam Sistem Politik Di Indonesia," Jurnal Pendidikan Islam Indonesia Vol 2, no. 1 Oktober 2017, h. 79.

${ }^{12}$ Riant Nurgoho, Kebijakan Publik : Formulasi, Implementasi Dan Evaluasi /D. Riant Nugroho (Jakarta: Elex Komputerindo, 2009). h. 135.

${ }^{13}$ M. Sutapa, "Kebijakan Pendidikan Dalam Perspektif Kebijakan Publik," Jurnal Manajemen Pendidikan UNY, no. 02 (2008). h. 13.

${ }^{14}$ https://www.cnnindonesia.com/ekonomi/20210302130004-532-612629/jokowi-cabutperpres-izin-investasi-miras
} 
kebijakan publik yang dikeluarkan oleh pemerintah harus benar-benar berpihak kepada kemaslahatan umat yaitu rakyat. Karena, apabila suatu kebijakan publik dalam bentuk keputusan maupun peraturan yang dibuat tanpa keberpihaka kepada masyarakat atau rakyat, maka akan berdampak pula pada implementasi suatu kebijakan publik tersebut tidak akan berjalan dengan baik sebagaimana mestinya. Oleh sebab itu, berkaca kepada kasus yang terjadi di atas, maka bisa kita simpulkan pula bahwa setiap kebijakan publik yang akan dikeluarkan, terlebih dahulu harus dilakukan perumusan dengan sebaik-baiknya, serta dilakukan sosialisasi kerangka acuan kebijakan public tersebut dalam bentuk workshop atau seminar guna mendapatkan masukan dari berbagai komponen, tujuannya ialah agar kebijakan publik yang dikeluarkan pada akhirnya tidak terdapat penolakan dari rakyat. Untuk itu, para pemangku kepentingan harus benar-benar memastikan bahwa kebijakan publik yang dilahirkan adalah untuk rakyat dan berpihak kepada rakyat bukan untuk kepentingan elit politik semata.

\section{Proses Kebijakan Publik}

Proses kebijakan publik merupakan salah satu kegiatan utama yang harus dilewati saat suatu kebijakan akan dirumuskan. Proses analisis kebijakan publik adalah serangkaian aktivitas intelektual yang dilakukan di dalam proses kegiatan yang bersifat politis. Semua aktifitas politis tersebut mencakup penyusunan agenda, formulasi kebijakan, adopsi kebijakan, implementasi kebijakan, dan penilaian kebijakan. Sedangkan aktivitas perumusan masalah, forecasting, rekomendasi kebijakan, monitoring, dan evaluasi kebijakan. Pentingnya proses kebijakan publik sangat penting diperhatikan bagi tiap-tiap suatu kebijakan akan dilahirkan. Banyak pakar dan peneliti juga mengungkapkan bahwa, apabila suatu kebijakan publik dilahirkan tanpa melalui proses kebijakan, maka akan berdampak pada implementasi kebijakan yang telah disahkan tidak berjalan sebagaimana mestinya. Amirul Haq dalam presentasinya tentang Kebijakan Publik juga mengungkapkan bahwa setidaknya setiap kebijakan publik yang akan dilahirkan untuk masyarakat harus mengikuti 6 (enam) Proses Kebijakan diantaranya ialah: 1) perumusan kebijakan; 2) penyusunan agenda; 3) perumusan usulan kebijakan; 4) pengesahan kebijakan; 5) pelaksanaan kebijakan; dan 6) penilaian kebijakan. Ke enam proses kebijakan tersebut secara jelasnya dapat dilihat pada bagan berikut ini: ${ }^{15}$

${ }^{15}$ Amirul Haq RD, Kebijakan Pendidikan sebagai Kebijakan Publik, (Yogyakarta: Universitas Islam Negeri Sunan Kalijaga, 2020). h. 8. 
Gambar 1 Skema Proses Kebijakan Publik

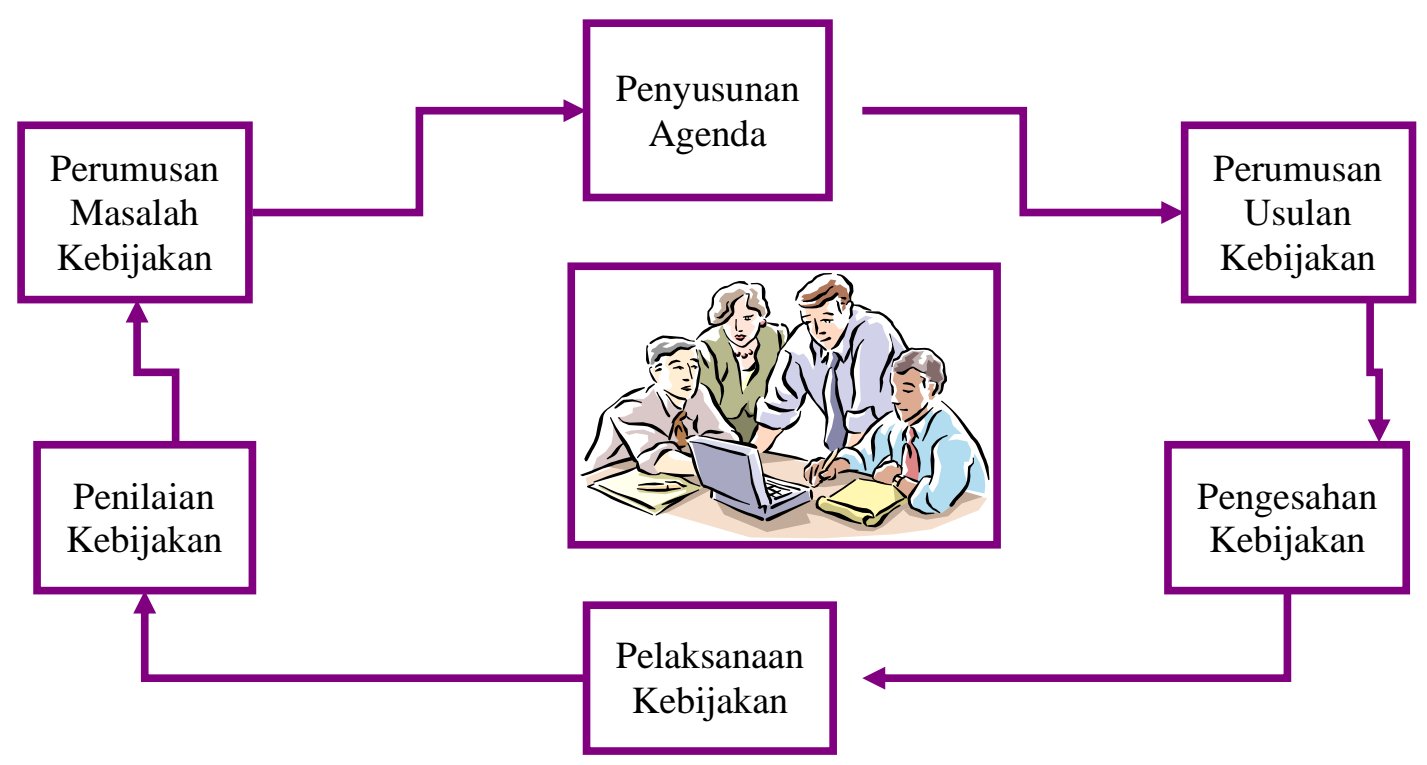

Berkaca pada proses kebijakan di atas pula, Alamsyah berpendapat bahwa terdapat 14 pendekatan dalam perumusan 'Kebijakan Publik' diantaranya ialah sebagai berikut: ${ }^{16}$

a. Pendekatan Kelompok: Pendekatan ini terjadi ketika beberapa individu mempunyai kepentingan yang sama dalam satu hal/perkara kemudian bergabung dan membentuk suatu kelompok, sehingga kelompok tersebut mampu mempengaruhi pemerintah dalam mengambil kebijakan. Kelompok tersebut akan saling mencari pengaruh untuk mencapai tujuan yang dimaksud. Seperti; dalam pembentukan koalisi partai politik, maupun kegiatan koalisi lainnya yang mengatasnamakan perwakilan masyarakat dalam penyampaian aspirasi.

b. Pendekatan Fungsional, yaitu suatu pendekatan dengan memusatkan perhatian pada kegiatan yang memiliki fungsi dalam proses kebijakan. Ada beberapa analisis yang dirumuskan dalam asas pendekatan fungsional yaitu:

1) Intelegensi: Informasi berkaitan dengan persoalan-persoalan kebijakan yang mendapat perhatian oleh pembuat kebijakan atau stakeholder kebijakan dikumpulkan dan kemudian diproses.

2) Rekomendasi: yaitu berupa rumusan yang berupa masukan untuk mengatasi suatu permasalahan.

3) Aplikasi: bentuk pelaksanaan atau penerapan yang sebenarnya dari sebuah peraturan.

\footnotetext{
${ }^{16}$ Kamal Alamsyah, Kebijakan Publik Konsep dan Aplikasi, (Bandung: Media Citra, 2016), h.
} $39-44$. 
4) Penilaian: evaluasi pelaksanaan kebijakan baik capaianya keberhasilan maupun kegagalannya; dan

5) Terminasi: titik akhir dari proses kebijakan publik baik itu peraturan maupun undang-undang, baik yang semula dihentikan atau dilanjutkan dalam bentuk yang telah dimodifikasi.

c. Pendekatan kelembagaan merupakan suatu pendekatan kebijakan publik yang diambil secara otoritatif oleh lembaga yang sah pemerintahan, misalnya lembaga legislatif maupun eksekutif. Dimana, kebijakan dengan pedekatan tersebut memiliki beberapa sifat khas yaitu mampu memberikan suatu kepastian atas kebijakan yang dikeluarkan, dan bersifat menyeluruh dan dapat menjangkau seluruh kalangan masyarakat, serta kebijakan yang dikeluarkan mempunyai kewenangan untuk menjatuhkan sanksi bagi pelanggar atau yang tidak melaksanakan/mematuhi atas kebijakan tersebut. Namun, kebijakan model ini juga mempunyai kelemahan tersendiri dari segi substansi. Sebagai contoh kebijakan Pemerintah Aceh tentang penerapan stickering mobil pemaka BBM subsidi yang diterbitkan melalui Surat Edaran Gubernur Aceh Nomor: 540/9186 Tahun 2020 yang pada akhirnya dicabut kembali. ${ }^{17}$

d. Pendekatan Peran Serta Warga Negara adalah suatu pendekatan peran serta masyarakat yang didasarkan kepada suatu teori demokrasi klasik, yang menekankan kepada peran serta masyarakat dan memberikan pengaruh yang baik dalam perkembangan suatu kebijakan publik. Keikutsertaan aktif masyarakat dalam suatu problem yang terjadi diharapkan agar masyarakat memperoleh pemahaman dan pengetahuan, serta rasa tanggung jawab sosial.

e. Pendekatan Psikologis. Menurut Ichsan, pendekatan psikologis dalam suatu kebijakan merupakan suatu pendekatan yang berkaitan dengan hubungan antar pribadi dan faktor jiwa seseorang yang dapat mempengaruhi tingkah laku dalam proses pelaksanaan suatu kebijakan. ${ }^{18}$ Dalam pendekatan psikologis ini, juga terlihat sejauh mana pertimbangan seseorang dalam mengambil kebijakan, apakah dipengaruhi oleh jiwa seseorang maupun sekelompok orang, ataukah ada indikator-indikator lain yang mempengaruhi jiwanya. Sehingga akan berdampak pula pada suatu kebijakan yang diputuskan.

f. Pendekatan Proses bertujuan untuk mengidentifikasi tahapan proses dalam suatu kebijakan publik dan menganalisis proses tersebut, sehingga akan tergambarkan berbagai kendala dan hambatan.

\footnotetext{
${ }^{17}$ Humas. Acehprov, “Aceh Terapkan Stickering Mobil Pemakai BBM Bersubsidi,” 2020, http://humas.acehprov.go.id/aceh-terapkan-stickering-mobil-pemakai-bbm-bersubsidi/.

${ }^{18}$ Muhammad Ichsan, "Psikologi Pendidikan dan Ilmu Mengajar," Jurnal Edukasi: Jurnal Bimbingan Konseling Vol 2, No. 1 (2016). h. 62.
} 
g. Pendekatan Subtantif yaitu suatu pendekatan dalam suatu bidang tertentu, misalnya menganalisis faktor apa sajakah yang menentukan dari perumusan suatu kebijakan publik.

h. Pendekatan Logis-positivis yaitu suatu pendekatan dalam kebijakan publik yang mengacu kepada perilaku atau keilmuan.

i. Pendekatan Ekonomentrik adalah pendekatan pilihan publik atau pendekatan kepada politic economic (ekonomi politik).

j. Pendekatan Fenomenologik/Pospositivis adalah suatu pendekatan fenomena dengan menggunakan metode keilmuan tertentu.

k. Pendekatan Partisipatori merupakan suatu pendekatan yang memberikan perhatian besar pada nilai-nilai dalam proses pembuatan keputusan atau suatu kebijakan.

1. Pendekatan normatif atau preskriptif adalah seorang analis perlu mendefinisikan tugasnya sebagai analis kebijakan sama seperti orang yang mendefinisikan "end state" dalam arti bahwa preskripsi ini bisa diinginkan dan bisa dicapai. ${ }^{19}$

m. Pendekatan Ideologis: Pendekatan ideologis, adalah secara eksplisit mengadopsi pandangan konservatif atau pandangan liberal, Thomas Sowell menamakan pendekatan ideologi ini "visi" (visions) dan mengidentifikasi dua perspektif yang bersaing. Yaitu pertama "visi yang dibatasi" the constrained vision merupakan suatu gambaran manusia egosenttrik dengan keterbatasan moral. Kedua, the unconstrained vision "visi yang tidak dibatasi" memberikan suatu pandangan tentang sifat manusia di mana pemahaman dan kecenderungan manusia adalah mampu untuk memperoleh keuntungan-keuntungan sosial.

n. Pendekatan Historis atau Sejarah: Pendekatan historis atau sejarah, adalah makin meningkatkan perhatian mereka kepada evolusi kebijakan publik melintasi waktu.

Tahapan analisis kebijakan ,Sujianto berpendapat bahwa tahapan analisis ataupun proses perumusan kebijakan publik dapat dirincikan sebagai berikut: ${ }^{20}$

1) Perumusan masalah berupa memberikan informasi mengenai kondisikondisi yang menimbulkan masalah.

2) Forecasting (Peramalan) berupa memberikan informasi mengenai konsekuensi di masa mendatang dari penerapan alternatif kebijakan, termasuk apabila tidak membuat kebijakan.

3) Rekomendasi kebijakan berupa memberikan informasi mengenai manfaat bersih dari setiap alternatif, dan merekomendasikan alternatif kebijakan yang memberikan manfaat bersih paling tinggi.

${ }^{19}$ Arwildayanto dkk, Analisis Kebijakan Pendidikan: Kajian Teoritis, Eksporatif, Dan Aplikatif, CV Cendikia Press, (Bandung: CV Cendikia Press, 2018). h. 9.

${ }^{20}$ Sujianto, Implementasi Kebijakan Publik Konsep, Teori Dan Praktik (Pekanbaru: Alaf Riau, 2008). h. 38. 
4) Monitoring kebijakan dengan memberikan informasi mengenai konsekuensi sekarangdan masa lalu dari diterapkannya alternatif kebijakan termasuk kendala-kendalanya.

5) Evaluasi Kebijakan berupa memberikan informasi mengenai kinerja.

Adapun urutan proses pengambilan kebijakan dapat dilihat pada skema di bawah ini:

Gambar 2 Proses Perumusan kebijakan Publik

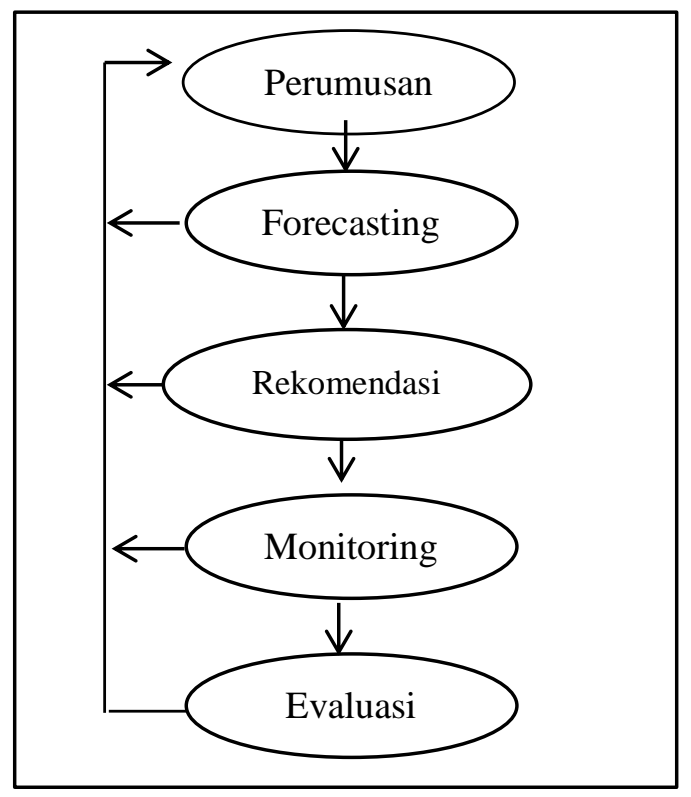

Sedangkan Islami dalam bukunya Prinsip-Prinsip Perumusan Kebijaksanaan Negara mengemukakan ada empat langkah dalam proses pengambilan kebijakan publik, yaitu: ${ }^{21}$

a) Perumusan Masalah Kebijakan. Tahapan perumusan masalah adalah upaya-upaya menemukan dugaan-dugaan yang tersembunyi, mendiaognosis penyebab-penyebabnya, memetakan tujuan-tujuan yang memungkinkan, meyatukan padangan yang bertentangan dan rancangan peluang kebijakan baru. Proses kebijakan publik di mulai dengan kegiatan merumuskan masalah secara benar, karena keberhasilan atau kegagalan dalam melaksanakan perumusan kebijakan ini akan sangat berpengaruh pada proses pembuatan kegiatan ini akan sangat berpengaruh pada proses pembuatan kebijaksanaan seterusnya. Perumusan Masalah-masalah publik dapat dikategorikan ke dalam beberapa kategori. Kategori pertama, masalah publik dapat dibedakan menjadi masalah prosedural dan masalah substantif. Masalah prosedural berhubungan dengan cara pemerintah diorganisasikan dan cara pemerintah melakukan tugas-tugasnya,

${ }^{21}$ M. Irfan Islamy, Prinsip-Prinsip Perumusan Kebijaksanaan Negara (Jakarta: Bumi Aksara, 2001). h. 77-14 
sedangkan masalah substantif berkaitan dengan akibat-akibat nyata dari kegiatan manusia. Kategori kedua, didasarkan pada asal-usul masalah. Berdasarkan kategori ini, masalah publik dapat dibedakan menjadi masalah luar negeri dan masalah dalam negeri. ${ }^{22}$

b) Agenda Kebijakan. Sekian banyak masalah-masalah umum yang muncul hanya sedikit yang mendapat perhatian dari pembuat kebijakan publik. Pilihan dan kecondongan perhatian pemuat kebijakan menyebabkan timbulnya agenda kebijakan. Sebelum masalah-masalah berkompotensi untuk masuk dalam agenda kebijakan, masalah tersebut akan berkompetisi dengan masalah yang lain yang pada akhirnya akan masuk dalam agenda kebijakan.

c) Pemilihan Alternatif Kebijakan untuk memecahkan masalah. Setelah masalah-masalah publik didefinisikan dengan baik dan para perumus kebijakan sepakat untuk memasukan masalah tersebut ke dalam agenda kebijakan, maka langkah selanjutnya adalah membuat pemecahan masalah. Perumusan usulan kebijakan (policy proposals) adalah kegiatan menyusun dan mengembangkan serangkaian tindakan yang perlu untuk memecahkan masalah. Proses dalam kegiatan ini meliputi: a) Mengidentifikasi altenatif; b) Mendefinisikan dan merumuskan alternative; c) Menilai masing-masing alternatif yang tersedia; dan d) Memilih alternatif yang memuaskan atau paling mungkin untuk dilaksanakan. ${ }^{23}$

d) Tahap penetapan kebijakan dan Impelementasi. Setelah salah satu dari sekian alternatif kebijakan diputuskan, untuk di ambil sebagai cara memercahkan masalah kebijakan, maka tahap paling akhir dalam pembuat kebijakan adalah penetapan kebijakan, sehingga mempunyai kekuatan hukum yang mengikat. Proses pembuatan kebijakan tidak dapat dipisahkan dengan proses penetapan atau pengesahan kebijakan. Tahapan penetapan dan implementasi merupakan tahapan tersulit dalam penetapaan kebijakan itu sendiri karena tidak akan berjalan mulus atau seperti membalikkan telapak tangan. Ada banyak faktor yang menjadi penyebab kegagalan dalam penerapan kebijakan yang diukur berdasarkan Aspek tersebut adalah keluaran (output) dan dampak (outcomes) kebijakan. ${ }^{24}$ Pada kenyataan yang terjadi di lapangan pada tahapan ini akan banyak bermunculan masalah-masalah. Dalam dunia pendidikan misalnya, penetapan Ujian Akhir Nasional (UAN) pada tahun 2005-2012 sebagai

\footnotetext{
${ }^{22}$ Sahya Anggara, Pengantar Kebijakan Publik, (Bandung: Pustaka Setia, 2016). h. 25.

${ }^{23}$ Kamal Alamsyah, Kebijakan Publik Konsep Dan Aplikasi, (Bandung: Media Citra, 2016), h. 50

${ }^{24}$ Shafiera Amalia, Analisis Implementasi Program Bank Sampah Di Kota Yogyakarta, Jurnal Analis Kebijakan Vol 1, no. 2 (2017). h. 37.
} 
syarat kelulusan juga dianggap tidak efektif karena banyak memunculkan banyak kecurangan seperti tersebarnya kunci jawaban, dan tidak mencakup penilaian afektif dan psikomotorik sebagai salah satu syarat kelulusan. Pada tahun 2020 kebijakan tersebut diubah menjadi Asesmen Kompetensi Minimum dan Survei Karakter. ${ }^{25}$

\section{Sistem dan Jenis Kebijakan Publik}

Terdapat 3 elemen penting dalam sebuah sistem kebijakan, yang satu sama lain saling berikatan, yaitu kebijakan publik, pelaku kebijakan dan lingkungan kebijakan. Hubungan antar elemen tersebut dilihat pada gambar berikut ini: ${ }^{26}$

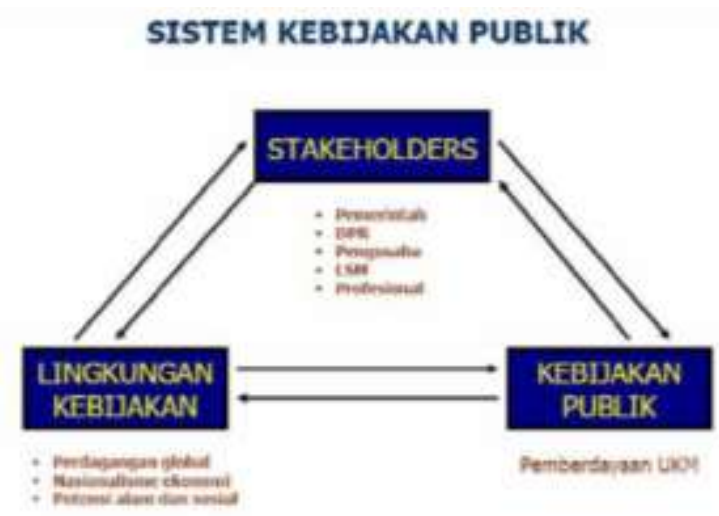

Gambar 3 Tiga Elemen Sistem Kebijakan

Sistem kebijakan mencakup beberapa komponen yang mana satu komponen dapat menjadi komponen yang lain melalui proses metodologi tertentu, seperti perumusan masalah, peramalan, saran-saran, pemantauan dan evaluasi. Melakukan analisis kebijakan berarti menggunakan kelima prosedur metodologi tersebut, yakni merumuskan masalah kebijakan, melakukan peramalan, membuat rekomendasi, melakukan pemantauan, dan melakukan evaluasi kebijakan. ${ }^{27}$ Jenis kebijakan publik memiliki banyak versi, bahkan para pakar mengajukan berbagai jenis menurut sudut pandang masing-masing. Adapun penulis hanya mencatumkan satu versi dari pandangan para ahli. Jenis kebijakan publik sebagaimana yang penulis kutip dalam buku Sahya Anggara sebagai berikut:

a) Kebijakan substantif dan kebijakan prosedural. Kebijakan Subtansif (Substantive policy) adalah kebijakan yang menyangkut apa yang akan dilakukan oleh pemerintah. Misalnya, kebijakan pendidikan, kebijakan ekonomi, dan lain-lain. Kebijakan prosedural (Procedural policy) adalah

\footnotetext{
${ }^{25}$ Peraturan Menteri Pendidikan dan Kebudayaan Republik Indonesia Nomor 43 Tahun 2019 Tentang Penyelengaraan Ujian Nasional Yang Diselenggarakan Satuan Pendidikan dan Ujian Nasional. 2015), h. 40.

${ }^{26}$ Abdal, Kebijakan Publik: Memahami Kebijkan Publik, (Bandung: UIN Sunan Gunung Djati,

${ }^{27}$ Taufiqurokhman, Kebijakan Publik, (Jakarta: Fakultas Ilmu Sosial dan Ilmu Politik Universitas Moestopo Beragama Pers, (2014). h. 23.
} 
kebijakan dilihat dari pihak-pihak yang terlibat dalam perumusannya (policy stakeholders) atau padangan bagaimana kebijakan subtansif tersebut dapat dijalankan. Misalnya peraturan tentang pendidikan maka yang berhak membuatnya adalah Kementerian Pendidikan. ${ }^{28}$ Akan tetapi, dalam pelaksanaan pembuatannya, banyak instansi/organisasi lain yang terlibat baik pemerintah maupun non-pemerintah, contoh organisasi non-pemerintah dalam dunia pendidikan adalah PGRI.

b) Kebijakan distributif dan kebijakan regulatori. Kebijakan Distributif (distributive policy) adalah bentuk kebijakan yang mengatur tentang pemberian pelayanan kepada individu, kelompok, atau perusahaan. Contoh, kebijakan tentang tax holiday, pembebasan lahan tanah untuk pembangunan jalan Tol atau lainnya untuk kepentingan umum. Kebijakan regulatori (regulatory policy) adalah kebijakan yang mengatur tentang pelarangan terhadap sesuatu hal atau pembatasannya, contohnya kebijakan tentang larangan mengkonsumsi Narkoba jenis Ganja.

c) Kebijakan Material. Kebijakan Material (Material policy) adalah kebijakan tentang pengalokasian sumber-sumber material kepada penerima secara langsung. Contoh, kebijakan pembuatan rumah sederhana/subsidi rumah.

d) Kebijakan barang umum dan privat. Kebijakan barang umum adalah kebijakan yang mengatur tentang penyediaan barang-barang/pelayanan oleh pemerintah untuk kepentingan orang banyak, contohnya seperti kebijakan tentang perlindungan keamanan dan, penyediaan jalan umum. Kebijakan barang privat adalah kebijakan yang mengatur tentang penyediaan barang-barang/pelayanan oleh pihak swasta untuk kepentingan individu (perseorangan) di pasar bebas dengan imbalan biaya tertentu, contohnya tempat hiburan, hotel, dan lainlain. $^{29}$

\section{METODE PENELITIAN}

Penelitian ini merupakan penelitian kualitatif dengan pendekatan deskriptif menyangkut tentang studi kebijakan publik terhadap kekhususan kebijakan pendidikan Aceh. Studi kebijakan publik dalam penelitian ini dimaksud untuk mengeksplorasi berbagai tindakan yang dilakukan pemerintah, mengapa tindakan itu dilakukan atau justru tidak dilakukan, dengan cara dan mekanisme apa dilakukan, untuk kepentingan siapa, dan bagaimana hasil, akibat dan dampaknya. Sehingga, dari kajian ini akan mendapatkan gambaran dan pemahaman mendalam tentang implementasi kebijakan publik di Aceh terutama menyangkut dengan penyelanggaraan pendidikan Aceh. Adapun subjek penelitian ini diambil dengan cara purposive sampling, dengan metode pengumpulan data dilakukan melalui 3 (tiga) macam cara yaitu; 1) observasi; 2) wawancara; dan 3) dokumentasi yaitu menganalisis isi kebijakan (content analysis),

\footnotetext{
${ }^{28}$ Suharno, Dasar-Dasar Kebijakan Publik (Yogyakarta: UNY Press, 2010). h. 28.

${ }^{29}$ Sahya Anggara, Pengantar Kebijakan Publik, (Bandung: Pustaka Setia, 2016). h. 55-56.
} 
mengkaji dokumen-dokumen berupa kategori administratif maupun substantif, diantaranya berupa berbagai bentuk kertas kerja hingga naskah akademik suatu kebijakan pendidikan di Aceh. Setelah rangkaian data terkumpul, selanjutnya dilakukan pula analisis data dengan prosedur dan teknis pengolahan berikut: 1) melakukan pemilahan dan penyusunan klasifikasi data, 2) melakukan penyuntingan data untuk membangun kinerja analisis data, 3) melakukan konfirmasi data yang memerlukan verifikasi data dan pendalaman data, dan 4) melakukan analisis data sesuai dengan konstruksi pembahasan hasil penelitian. Penyajian data dilakukan dengan menyusun sekumpulan informasi, sehingga berbentuk laporan final berdasarkan hasil kajian yang dilakukan.

\section{HASIL PENELITIAN DAN PEMBAHASAN}

\section{Analisis Kekhususan Kebijakan Pendidikan di Aceh}

Pendidikan mempunyai tugas menyiapkan sumber daya manusia untuk pembangunan. Derap langkah pembangunan selalu diupayakan seirama dengan tuntutan zaman. Perkembangan zaman selalu memunculkan persoalan-persoalan baru yang tidak pernah terpikirkan sebelumnya. Suatu pendidikan dipandang bermutu diukur dari kedudukannya untuk ikut mencerdaskan kehidupan bangsa dan memajukan kebudayaan nasional adalah pendidikan yang berhasil membentuk generasi muda yang cerdas, berkarakter, bermoral dan berkepribadian. Untuk itu perlu dirancang suatu sistem pendidikan yang mampu menciptakan suasana dan proses pembelajaran yang menyenangkan, merangsang dan menantang peserta didik untuk mengembangkan diri secara optimal sesuai dengan bakat dan kemampuannya. Memberikan kesempatan kepada setiap peserta didik berkembang secara optimal sesuai dengan bakat dan kemampuannya adalah salah satu prinsip pendidikan demokratis. $^{30}$

Pasca Damai Aceh 15 Agustus 2005 di Helsinki, sejalan dengan cita-cita untuk memajukan Aceh dari ketertinggalan dalam bidang pendidikan akibat konflik yang berkepanjangan dan tsunami yang menimpa Aceh 26 Desember 2004. Pemerintah Aceh telah merumuskan pula suatu kebijakan publik tentang pendidikan di Aceh, alasan utama dilakukan perumusan kebijakan khusus pendidikan Aceh diantaranya ialah sebagai bentuk implementasi dari Undang-Undang Nomor 11 Tahun 2006 tentang Pemerintah Aceh. ${ }^{31}$ Karena, isi utama yang telah diamanatkan oleh UndangUndang Nomor 11 Tahun 2006 tentang Pemerintahan Aceh (UUPA) adalah menjamin terlaksananya sistem pendidikan yang berbasis nilai Islami dan menjamin semua lulusan sekolah menengah dan perguruan tinggi dapat bersaing di pasar kerja global, regional, dan nasional serta menjadi dorongan untuk membangun kehidupan sosial

${ }^{30}$ Tim Penelitian dan Pengembangan Bappeda Aceh, Kajian Analisis Mutu Pendidikan Aceh, (Banda Aceh: Badan Perencanaan dan Pembangunan Daerah (BAPPEDA) Aceh, 2015), h. 2.

${ }^{31}$ Pemerintah Aceh, Undang-Undang Nomor 11 Tahun 2006 tentang Pemerintahan Aceh, (Banda Aceh: Biro Hukum Setda Aceh, 2006), h. 50. 
ekonomi, politik, dan kehidupan masyarakat Aceh lebih baik. ${ }^{32}$ Dengan ditetapkannya UUPA, perbaikan mutu pendidikan menjadi sangat strategis. lebih lagi dengan pemberian perhatian yang tinggi pada sektor ini sebagaimana diamanatkan dalam UUPA, Aceh memerlukan suatu arahan strategis jangka panjang dalam bidang pendidikan. Demikian pula UndangUndang Nomor 44 Tahun 1999 tentang Penyelenggaraan Keistimewaan Provinsi Daerah Istimewa Aceh, juga menekankan perlunya perhatian besar terhadap pendidikan. Keistimewaan yang diberikan kepada aceh adalah kewenangan khusus untuk menyelenggarakan kehidupan beragama, adat, pendidikan, dan peran ulama dalam penetapan kebijakan daerah. Berdasarkan UUPA, penyelenggaraan pendidikan merupakan salah satu urusan wajib yang menjadi kewenangan Pemerintah Aceh dalam skala Aceh adalah penyelenggaraan pendidikan dan alokasi sumber daya manusia potensial. Urusan wajib lainnya adalah penyelenggaraan pendidikan yang berkualitas serta menambah materi muatan lokal sesuai dengan syariat Islam. ${ }^{33}$

Berdasarkan latar belakang tersebut, pada tahun 2008 dibentuklah 1 (satu) aturan pelaksana dalam bentuk Qanun, yaitu Qanun Aceh Nomor 5 Tahun 2008 tentang Penyelenggaraan Pendidikan. Dalam perjalananya, ternyata pelaksanaan Qanun Aceh Nomor 5 Tahun 2008 tersebut, belum efektif dalam meningkatkan kualitas manusia di Aceh melalui pendidikan. ${ }^{34}$ Secara garis besar dikarenakan terdapatnya beberapa permasalahan utama antara lain:

a. Para pemangku kepentingan juga menyoroti ketidakjelasan dalam hal pembagian kewenangan antar pelaksana program baik antar instansi maupun antara provinsi dan kabupaten/kota. pembahasan mengenai pembagian kewenangan, khusus untuk penyelenggaraan pendidikan yang menjadi tanggung jawab Kabupaten/Kota yang saat ini masih dalam pembahasan oleh pemerintah aceh perlu segera dibahas lebih lanjut;

b. Disamping itu, perhatian perlu diberikan kepada isu-isu penting yang terabaikan seperti pengaturan tentang Standar Pelayanan Minimal (SPM) dalam bidang pendidikan dan Standar Nasional Pendidikan (SNP);

c. Belum jelasnya penjabaran konsep pendidikan islami;

d. Terdapat pasal-pasal yang masih berkesan diskriminatif bagi siswa non muslim;

e. Isu pendidikan gratis yang tidak menguntungkan dunia pendidikan dan siswa kurang mampu;

f. Tidak ada penjelasan tentang pendidikan layanan khusus;

g. Beberapa pasal perlu disesuaikan substansi dengan peraturan yang baru;

\footnotetext{
${ }^{32}$ Pemerintah Aceh, Penjelasan Qanun Aceh Nomor 11 Tahun 2014 tentang Penyelenggaraan Pendidikan, (Banda Aceh: Biro Hukum Pemerintah Aceh, 2014), h. 2

${ }^{33}$ Pemerintah Aceh, Penjelasan Qanun Aceh Nomor 11 Tahun 2014 tentang Penyelenggaraan Pendidikan..., h. 2

${ }^{34}$ Pemerintah Aceh, Penjelasan Qanun Aceh Nomor 11 Tahun 2014 tentang Penyelenggaraan Pendidikan..., h. 2-3.
} 
h. Adanya pasal yang tidak diperlukan karena satu sama lain memiliki kesamaan redaksional. Intinya menghendaki perubahan beberapa ketentuan yang tercantum dalam Qanun Aceh Nomor 5 Tahun 2008 tersebut, dengan harapan akan terjadi peningkatan kualitas penyelenggarakan pendidikan di Aceh. Oleh karena itu, dengan adanya Qanun Aceh tentang Penyelenggaraan Pendidikan yang baru diharapkan akan dapat mendukung efektifivitas implementasi strategi dan kebijakan yang disusun oleh berbagai lembaga pemerintah yang berkaitan dengan sektor pendidikan. ${ }^{35}$

Pemerintah Aceh pada tahun 2014 berhasil menerbitkan Lembaran Daerah baru dalam bentuk Peraturan Daerah yaitu Qanun Aceh Nomor 11 Tahun 2014 tentang Penyelengaraan Pendidikan, dengan Nomor 12 Tahun 2014. ${ }^{36}$ Lahirnya Qanun Aceh Nomor 11 Tahun 2014 tersebut merupakan salah satu bentuk kebijakan Pemerintah Aceh dalam bidang pendidikan untuk merealisasikan butir-butir sebagaimana yang tercantum dalam kekhususan Aceh. Dengan lahirnya kebijakan pendidikan Aceh, diharapkan akan dapat mempercepat pencapaian tujuan dan target kebijakan nasional mengenai pendidikan untuk semua (education for all), dalam rangka pelaksanaan pesan Pasal 216 Undang-Undang Nomor 11 Tahun 2006 tentang Pemerintahan Aceh, yaitu setiap penduduk Aceh berhak mendapat pendidikan yang bermutu dan Islami sejalan dengan perkembangan ilmu pengetahuan dan teknologi yang diselenggarakan atas dasar prinsip-prinsip demokrasi dan keadilan dengan menjunjung tinggi hak asasi manusia, nilai islami, budaya, dan kemajemukan bangsa. ${ }^{37}$ Pemerintah Aceh juga berhak mengatur pendidikannya sendiri berdasarkan ciri khas agama Islam pada lembaga pendidikan di Aceh yang dilaksanakan dalam bentuk diantaranya: 1) Mata Pelajaran; 2) Suasana keagamaannya pada lembaga pendidikannya yang akademis; dan 3) Pengintegrasian Pendidikan Islam ke dalam mata pelajaran umum. ${ }^{38}$ Sehingga, Esensinya ialah bahwa pendidikan Islam di Aceh hendaknya dirancang dan diarahkan untuk membimbing, melatih, serta mengajarkan peserta didik menjadi manusia muslim yang berkualitas Islami. Dalam arti mampu mengembangkan pandangan hidup, sikap dan ketrampilan hidup yang berperspektif Islami.

Kemudian, pada tahun 2015 dilakukan pula perubahan atas Qanun Aceh Nomor 11 Tahun 2014 tentang Penyelenggaraan Pendidikan, terutama yang menyangkut dengan pembagian kewenangan Penyelenggaraan Pendidikan antara Pemerintah Aceh dengan Pemerintah Kabupaten/Kota. Hal ini dilakukan oleh Pemerintah Aceh dalam rangka menyesuaikan diri dengan kebijakan pusat. Dimana,

\footnotetext{
${ }^{35}$ Pemerintah Aceh, Penjelasan Qanun Aceh Nomor 11 Tahun 2014 tentang Penyelenggaraan Pendidikan...,h. 3-4.

${ }^{36}$ Qanun Aceh Nomor 11 Tahun 2014 tentang Penyelenggaraan Pendidikan mulai berlaku ditetapkan pada 22 Oktober 2014 oleh Gubernur Aceh dr. Zaini Abdullah, dan diundangkan pada tanggal 23 Oktober 2014 oleh Sekretaris Daerah Aceh Darmawan; Lihat Lembaran Aceh Nomor 12 Tahun 2014 tentang Qanun Aceh Nomor 11 Tahun 2014 tentang Penyelenggaraan Pendidikan, (Banda Aceh: Biro Hukum Setda Aceh, 2014), h. 1-53.

${ }^{37}$ Pemerintah Aceh, Penjelasan Qanun Aceh Nomor 11 Tahun 2014 tentang Penyelenggaraan Pendidikan..., h. 2-3.

${ }^{38}$ Darwis A. Soelaiman, Kurikulum Aceh..., h. 3.
} 
pada tahun 2014 telah diundangkan Undang-Undang baru tentang Pemerintah Daerah yaitu Undang-Undang Nomor 23 Tahun 2014 tentang Pemerintahan Daerah yang diundangkan pada tanggal 30 September 2014. ${ }^{39}$ Lahirnya Undang-Undang tersebut merupakan penggantian terhadap Undang-Undang Nomor 32 Tahun 2004 tentang Pemerintahan Daerah, karena dianggap sudah tidak sesuai lagi dengan perkembangan zaman dan tuntunan otonomi daerah. Khususnnya berkaitan dengan pembagian urusan pemerintahan pusat dengan pemerintahan daerah menyangkut dalam bidang Pendidikan. ${ }^{40}$ Oleh karena itu, dalam Undang-Undang baru tersebut telah terjadi pula kewenangan baru pengelolaan pendidikan, baik menyangkut dengan kewenangan Pemerintah, Kewenangan Provinsi maupun Kewenangan Kabupaten/Kota. Adanya perubahan ini tentunya berimplikasi pula pada kewenangan pengelolaan Penyelenggaraan Pendidikan di Aceh. ${ }^{41}$ Maka Pemerintah Aceh pada tahun 2015 telah melakukan pula perubahan terhadap kebijakan pendidikan dengan menyesuaikan atas kebijakan pendidikan nasional dalam Peraturan Daerah atau Lembar Daerah Tahun 2015 yaitu Qanun Aceh Nomor 9 Tahun 2015 tentang Perubahan Atas Qanun Aceh Nomor 11 Tahun 2014 tentang Penyelenggaraan Pendidikan, yang ditetapkan pada tanggal 31 Desember 2015 oleh Gubernur Aceh dr. Zaini Abdullah, dan diundangkan pada tanggal 8 Januari 2015 dalam Lembar Daerah Aceh Nomor 3 Tahun 2015. ${ }^{42}$ Dengan adanya perubahan kebijakan pendidikan Aceh dalam Qanun Aceh Nomor 9 Tahun 2015 tersebut, maka diharapkan pula sektor pendidikan Aceh akan berjalan sesuai dengan harapan, bermutu dan berdaya saing.

Berdasarkan analisis terhadap kebijakan pendidikan Aceh pula, maka dapat penulis simpulkan bahwa kebijakan pendidikan di Aceh merupakan salah satu kekhususan yang diberikan Pemerintah Pusat kepada Aceh sesuai dengan ketentuan dalam Undang-Undang Nomor 11 Tahun 2006 tentang Pemerintah Aceh (UUPA) pada BAB XXX tentang Pendidikan. ${ }^{43}$ Oleh sebab itu, guna implementasi UUPA tersebut, maka dirumuskanlah kebijakan khusus dalam bentuk Qanun Aceh tentang Penyelenggaraan Pendidikan guna pendidikan yang dilaksanakan di Aceh sepenuhnya memenuhi standard minimal.

Kemudian, berdasarkan analisis kebijakan yang diberikan terhadap Aceh dalam Undang-Undang Nomor 11 Tahun 2006 tentang Pemerintahan Aceh dalam bidang pendidikan, bisa penulis simpulkan bahwa landasan di atas mengandung makna bahwa Aceh telah diberikan kekhususan bagi pendidikan untuk mengakomodasi aspirasi masyarakat di Aceh. Melalui kebijakan yang telah ada pula, sangat menghendaki agar sistem pendidikan dikembangkan dengan menekankan pola Sistem

${ }^{39}$ Undang-Undang Nomor 23 Tahun 2014 tentang Pemerintahan Daerah.

${ }^{40}$ Undang-Undang Nomor 32 Tahun 2004 tentang Pemerintahan Daerah.

${ }^{41}$ Pemerintah Aceh, Penjelasan Qanun Aceh Nomor 9 Tahun 2015 tentang Perubahan Atas Qanun Aceh Nomor 11 Tahun 2014 tentang Penyelenggaraan Pendidikan..., h. 1-2.

${ }^{42}$ Lembar Daerah Nomor 3 Tahun 2015 tentang Qanun Aceh Nomor 9 Tahun 2015 tentang Perubahan Atas Qanun Aceh Nomor 11 Tahun 2014 tentang Penyelenggaraan Pendidikan (Banda Aceh: Biro Hukum Setda Aceh, 2015), h. 1-10.

${ }^{43}$ Pemerintah Aceh, Undang-Undang Nomor 11 Tahun 2006 tentang Pemerintahan Aceh..., h. 72. 
Pendidikan Islami atau Sistem Pendidikan Berbasis Nilai-Nilai Islami (penekanannya pada penanaman nilai-nilai Islami dan pengembangan budaya islami). Hal ini tentu mempunyai alasan kuat, karena Aceh merupakan salah satu provinsi di Indonesia yang menerapkan syariat Islam. Oleh karena sangat kental dengan Syariat Islam tersebut pula, maka berdasarkan kebijakan pendidikan yang telah ditetapkan, Pemerintah Aceh sangat menginginkan adanya sistem pendidikan Islami di Aceh, dimana ada integrasi tambahan materi pelajaran agama Islam dan nilai-nilai islami serta mata pelajaran muatan lokal Aceh, serta yang dilaksanakan secara Islami. Namun, tidak mengubah kurikulum nasional, melainkan adanya tambahan muatan lain, atau dalam kata lain Pemerintah Aceh menginginkan suatu konsep pendidikan baru di Aceh dengan istilah Sistem Pendidikan Nasional Plus Islami (Kurikukum Nasional ditambah materi pelajaran agama Islam dan nilai-nilai islami dan mata pelajaran muatan lokal Aceh, serta dilaksanakan secara Islami).

Maka guna merealisasikan sistem dan tata kelola sebagaimana dimaksud yaitu pendidikan Islami di Aceh, maka Pemerintah Aceh melalui Instansi terkait harus merumuskan Kurikulum Aceg dan menetapkan model sistem pendidikan Islami di Aceh melalui suatu standar pendidikan Aceh sebagai parameter dalam pelaksanaan pendidikan Aceh. Cita-cita tersebut tentunya menjadi sangat kuat bagi Aceh. Karena, apabila dilihat dari sumber dana pendidikan, provinsi Aceh merupakan salah satu daerah yang mendapatkan dana otonomi khusus (otsus) dari pemerintah pusat yang cukup besar. Dana tersebut berasal dari dana otonomi khusus, dana bagi hasil migas dan dari sumber lain. ${ }^{44}$ Sehingga dari besarnya anggaran yang dikucurkan untuk pendidikan, memiliki harapan besar kualitas pendidikan Aceh akan bermutu, dan akan memiliki output dan outcome yang berbeda dengan provinsi lain di Indonesia.

Apalagi, pendidikan merupakan faktor penting guna menciptakan Sumber Daya Manusia yang handal, maka setiap kebijakan pendidikan yang dilahirkan tentu memiliki tujuan adalah menciptakan sistem pendidikan sesuai dengan harapan. Hampir semua negera maju memiliki kebijakan pendidikan yang implementasinya berjalan dengan baik, memenuhi kebutuhan rakyatnya, dan penuh tanggungjawab. Kembali kepada pengertian singkat dari kebijakan yaitu sebuah keputusan pemerintah memiliki sifat umum dan berlaku kepada seluruh lapisan masyarakat. Sehingga seluruh kebijakan tentang pendidikan merupakan bagian dari kebijakan publik itu sendiri. Kebijakan-kebijakan yang mengatur tentang pendidikan di Indonesia sudah sangat banyak, sehingga memberikan ruang gerak yang bebas pagi para penggerak pendidikan di Indonesia untuk terus meningkatkan kualitas pendidikan berkarakter dan mencapai tujuan pendidikan nasional semaksimal mungkin.

Sebagaimana dijelaskan dalam Undang-undang Nomor 20 tahun 2003 tentang Sistem Pendidikan Nasional adalah suatu usaha yang dilakukan penuh dengan kesadaran dalam rangka mewujudkan suasana pembelajaran aktif bagi peserta didik untuk mengembangkan seluruh potensi yang ada dalam peserta didik serta

${ }^{44}$ Tim Penelitian dan Pengembangan Bappeda Aceh, Kajian Analisis Mutu Pendidikan Aceh..., h. 4. 
keterampilan yang dibutuhkan bagi dirinya, masyarakat nusa dan bangsa. ${ }^{45}$ Seiring tuntutan zaman di era globalisasi, kebijakan pendidikan mengalami beberapa kali perubahan untuk dapat mencapai tujuan Pendidikan Nasional. Sebut saja, UndangUndang tentang Sistem Pendidikan Nasional, sejak tahun 2003 Undang-Undang sebelumnya telah diganti dengan Undang- Undang Nomor 20 Tahun 2003, yang disahkan pada tanggal 11 Juni 2003. Maka tidak mengherankan pula, jika kadangkadang setiap kebijakan bisa saja berganti seketika. Karena harus mengikuti kondisi atau dinamika perubahan, baik nasional maupun global. Intinya, semua kebijakan pendidikan yang dilahirkan tidak lain ialah untuk mencerdaskan kehidupan rakyanya sesuai dengan pembukaan Undang-Undang Dasar 1945 alinea keempat menyebutkan bahwa "mencerdaskan kehidupan bangsa," dalam hal ini bangsa mencakup seluruh warga negara Indonesia baik warga yang belajar di sekolah-sekolah negeri, maupun yang belajar di sekolah swasta.

\section{KESIMPULAN}

Pemerintah Aceh telah merumuskan suatu kebijakan publik tentang pendidikan di Aceh yaitu Qanun Aceh Nomor 11 Tahun 2014 tentang Penyelenggaraan Pendidikan, dan Qanun Aceh Nomor 9 Tahun 2015 tentang Perubahan Atas Qanun Aceh Nomor 11 Tahun 2014 tentang Penyelenggaraan Pendidikan. Kebijakan pendidikan tersebut lahir sebagai bentuk implementasi dari Undang-Undang Nomor 11 Tahun 2006 tentang Pemerintah Aceh. Isi utama dalam kebijakan tersebut memuat secara rinci sebagaimana yang telah diamanatkan oleh Undang-Undang Nomor 11 Tahun 2006 tentang Pemerintahan Aceh (UUPA). Melalui kebijakan yang telah dirumuskan berdasarkan Qanun Aceh itu pula, Pemerintah Aceh sangat menghendaki agar sistem pendidikan dikembangkan dengan menekankan pola Sistem Pendidikan Islami atau Sistem Pendidikan Berbasis Nilai-Nilai Islami (penekanannya pada penanaman nilai-nilai Islami dan pengembangan budaya islami). Hal ini tentu mempunyai alasan kuat, karena Aceh merupakan salah satu provinsi di Indonesia yang menerapkan syariat Islam. Oleh karena sangat kental dengan Syariat Islam tersebut pula, maka berdasarkan kebijakan pendidikan yang telah ditetapkan, Pemerintah Aceh sangat menginginkan adanya sistem pendidikan Islami di Aceh, dimana ada integrasi tambahan materi pelajaran agama Islam dan nilai-nilai islami serta mata pelajaran muatan lokal Aceh, serta yang dilaksanakan secara Islami. Namun, tidak mengubah kurikulum nasional, melainkan adanya tambahan muatan lain, atau dalam kata lain Pemerintah Aceh menginginkan suatu konsep pendidikan baru di Aceh dengan istilah Sistem Pendidikan Nasional Plus Islami (Kurikukum Nasional ditambah materi pelajaran agama Islam dan nilai-nilai islami dan mata pelajaran muatan lokal Aceh, serta dilaksanakan secara Islami).

\section{DAFTAR PUSTAKA}

45 
Abdal, Kebijakan Publik: Memahami Kebijkan Publik, Bandung: UIN Sunan Gunung Djati, 2015.

Amirul Haq RD, Kebijakan Pendidikan sebagai Kebijakan Publik, Yogyakarta: Universitas Islam Negeri Sunan Kalijaga, 2020.

Arwildayanto dkk, Analisis Kebijakan Pendidikan: Kajian Teoritis, Eksporatif, Dan Aplikatif, CV Cendikia Press, Bandung: Cendikia Press, 2018.

Darwis A. Soelaiman, Kurikulum Aceh, Banda Aceh: Majelis Pendidikan Aceh, 2018.

https://www.cnnindonesia.com/ekonomi/20210302130004-532-612629/jokowicabut-perpres-izin-investasi-miras

Humas. Acehprov, "Aceh Terapkan Stickering Mobil Pemakai BBM Bersubsidi," 2020, http://humas.acehprov.go.id/aceh-terapkan-stickering-mobil-pemakaibbm-bersubsidi/.

Kamal Alamsyah, Kebijakan Publik Konsep dan Aplikasi, Bandung: Media Citra, 2016.

Kamal Alamsyah, Kebijakan Publik Konsep Dan Aplikasi, Bandung: Media Citra, 2016.

Kementerian Pendidikan dan Kebudayaan, Kamus Besar Bahasa Indonesia, Jakarta: Direktorat Pendidikan Kemnterian Pendidikan dan Kebudayaan Republik Indonesia, 2018.

Lembar Daerah Nomor 3 Tahun 2015 tentang Qanun Aceh Nomor 9 Tahun 2015 tentang Perubahan Atas Qanun Aceh Nomor 11 Tahun 2014 tentang Penyelenggaraan Pendidikan (Banda Aceh: Biro Hukum Setda Aceh, 2015.

Lembaran Aceh Nomor 12 Tahun 2014 tentang Qanun Aceh Nomor 11 Tahun 2014 tentang Penyelenggaraan Pendidikan, (Banda Aceh: Biro Hukum Setda Aceh, 2014.

M. Irfan Islamy, Prinsip-Prinsip Perumusan Kebijaksanaan Negara, Jakarta: Bumi Aksara, 2001.

M. Sutapa, "Kebijakan Pendidikan Dalam Perspektif Kebijakan Publik," Jurnal Manajemen Pendidikan UNY, No. 02 (2008), 13.

Majelis Permusyawaratan Rakyat Republik Indonesia, Materi Sosialisasi Empat Pilar MPR RI, Jakarta; Sekretariat Jenderal MPR RI, 2017.

Majelis Permusyawaratan Rakyat Repulik Indonesia, Undang-Undang Dasar Negara Republik Indonesia Tahun 1945, Jakarta: Sekretariat Jenderal MPR RI, 2017.

Maskuri, "Kebijakan Pendidikan Sebagai Kebijakan Publik Dalam Sistem Politik Di Indonesia,” Jurnal Pendidikan Islam Indonesia Vol 2, No. 1 Oktober (2017), 79.

Muhammad Ichsan, "Psikologi Pendidikan dan Ilmu Mengajar," Jurnal Edukasi: Jurnal Bimbingan Konseling Vol 2, No. 1 (2016), 62. 
Nazamuddin, Pendanaan Pendidikan Aceh Melalui Dana Otonomi Khusus, dalam Pendidikan Aceh: Dinamika dan Harapan, Yogyakarta: Penerbit Pale Media Prima dan Majelis Pendidikan Aceh (MPA), 2020.

Pemerintah Aceh, Penjelasan Qanun Aceh Nomor 11 Tahun 2014 tentang Penyelenggaraan Pendidikan, Banda Aceh: Biro Hukum Pemerintah Aceh, 2014.

Pemerintah Aceh, Qanun Aceh Nomor 9 Tahun 2015 tentang Perubahan atas Qanun Nomor 11 Tahun 2014 tentang Penyelenggaraan Pendidikan di Aceh, Banda Aceh: Biro Hukum Setda Aceh, 2015.

Pemerintah Aceh, Qanun Aceh Tahun 2014 tentang Penyelenggaraan Pendidikan di Aceh, Banda Aceh: Biro Hukum Setda Aceh, 2014.

Pemerintah Aceh, Undang-Undang Nomor 11 Tahun 2006 tentang Pemerintahan Aceh, Banda Aceh: Biro Hukum Setda Aceh, 2006.

Peraturan Menteri Pendidikan dan Kebudayaan Republik Indonesia Nomor 43 Tahun 2019 Tentang Penyelengaraan Ujian Nasional Yang Diselenggarakan Satuan Pendidikan dan Ujian Nasional.

Rahmad Syah Putra, Reza Hendra Putra, Amirul Haq RD, Konsepsi Ideal Darussalam dalam Perspektif A. Hasjmy sebagai Pusat Pendidikan Islam, dalam Adabiya, Volume 22 No. 2 Agustus (2020), 1-10.

Rahmad Syah Putra, Strategi Peningkatan Mutu Pendidikan pada SMA Negeri 3 Meulaboh, dalam Jurnal Administrasi Pendidikan Vol. 5 Nomor 3 Agustus (2017), 163-164.

Riant Nurgoho, Kebijakan Publik: Formulasi, Implementasi Dan Evaluasi /D. Riant Nugroho Jakarta: Elex Komputerindo, 2009.

Ruqaiyah \& Rahmad Syah Putra, Pendidikan sebagai Investasi Sumber Daya Manusia untuk Mengelola Sumber Daya Alam, dalam Aceh 2021: Sumber Daya Alam dan Politik, Banda Aceh: Bandar Publishing, 2021.

Sahya Anggara, Pengantar Kebijakan Publik, Bandung: Pustaka Setia, 2016.

Shafiera Amalia, Analisis Implementasi Program Bank Sampah di Kota Yogyakarta, Jurnal Analis Kebijakan Vol 1, No. 2 (2017), 37.

Solichin Abdul Wahab, Analisis Kebijaksanaan: Dari Formulasi Ke Implementasi Kebijaksanaan Negara, Jakarta: Bumi Aksara, 2008.

Suharno, Dasar-Dasar Kebijakan Publik, Yogyakarta: UNY Press, 2010.

Sujianto, Implementasi Kebijakan Publik Konsep, Teori dan Praktik, Pekanbaru: Alaf Riau, 2008. 
ISSN: 2085-2541

Taufiqurokhman, Kebijakan Publik, Jakarta: Fakultas Ilmu Sosial dan Ilmu Politik Universitas Moestopo Beragama Pers, 2014.

Tim Penelitian dan Pengembangan Bappeda Aceh, Kajian Analisis Mutu Pendidikan Aceh, Banda Aceh: Badan Perencanaan dan Pembangunan Daerah (BAPPEDA) Aceh, 2015. 